\title{
Exposure to dust in poultry: the importance of task differences for detailed exposure assessment
}

\author{
S. Viegas ${ }^{1}$, M. Almeida-Silva ${ }^{1,2} \&$ C. Viegas ${ }^{1}$ \\ ${ }^{1}$ Lisbon College of Health Technology, Lisboa, Portugal \\ ${ }^{2}$ Nuclear and Technological Institute, Sacavém, Portugal
}

\begin{abstract}
Dust is a complex mixture of particles of organic and inorganic origin and different gases absorbed in aerosol droplets. In a poultry unit include dried faecal matter and urine, skin flakes, ammonia, carbon dioxide, pollens, feed and litter particles, feathers, grain mites, fungi spores, bacteria, viruses and their constituents. Dust particles vary in size and differentiation between particle size fractions is important in health studies in order to quantify penetration within the respiratory system. A descriptive study was developed in order to assess exposure to particles in a poultry unit during different operations, namely routine examination and floor turn over. Direct-reading equipment was used (Lighthouse, model 3016 IAQ). Particle measurement was performed in 5 different sizes (PM0.5; PM1.0; PM2.5; PM5.0; PM10). The chemical composition of poultry litter was also determined by neutron activation analysis. Normally, the litter of poultry pavilions is turned over weekly and it was during this operation that the higher exposure of particles was observed. In all the tasks considered PM5.0 and PM10.0 were the sizes with higher concentrations values. PM10 is what turns out to have higher values and PM0.5 the lowest values. The chemical element with the highest concentration was $\mathrm{Mg}\left(5.7 \mathrm{E} 6 \mathrm{mg} \cdot \mathrm{kg}^{-1}\right)$, followed by $\mathrm{K}\left(1.5 \mathrm{E} 4 \mathrm{mg} \cdot \mathrm{kg}^{-1}\right), \mathrm{Ca}\left(4.8 \mathrm{E} 3 \mathrm{mg} \cdot \mathrm{kg}^{-1}\right), \mathrm{Na}\left(1.7 \mathrm{E} 3 \mathrm{mg} \cdot \mathrm{kg}^{-1}\right), \mathrm{Fe}$ $\left(2.1 \mathrm{E} 2 \mathrm{mg} . \mathrm{kg}^{-1}\right)$ and $\mathrm{Zn}\left(4.2 \mathrm{E} 1 \mathrm{mg} \cdot \mathrm{kg}^{-1}\right)$. This high presence of particles in the respirable range $(<5-7 \mu \mathrm{m})$ means that poultry dust particles can penetrate into the gas exchange region of the lung. Larger particles (PM10) present a range of concentrations from 5.3E5 and $3.0 \mathrm{E} 6 \mathrm{mg} / \mathrm{m}^{3}$. The exposure to these kinds of particles can also cause disease by impacting in the upper and larger airways
\end{abstract}


below the vocal cords. The evidence of possible negative health effects related with this exposure suggests a need of remediation.

Keywords: poultry dust, occupational exposure, assessment of exposure by tasks, size of particles, health effects.

\section{Introduction}

Agricultural workers especially pig and poultry farmers are at increased risk of occupational respiratory diseases [1-5].

Dust is one of the risk factors present in animal housing and results from poultry residues, moulds and feather and may produce immune response against pathogenic biological agents. The response can be acute, recurrent or chronic in the lungs, depending mainly on the frequency and level of exposure [6].

Poultry dust is biologically active in that it contains micro-organisms, some of which may be pathogens, and a host of biological fragments which can act as sensitizers [7]. Several inflammatory agents are also present; among them is bacterial endotoxin, which has been shown to be related to the presence of decrease in spirometry and subjective symptoms $[8,9]$. Another biologically potent agent is (1/3)-b-D-glucan in the cell wall of moulds. This agent has a suppressive effect on the immune system and has been related to a higher risk for atopic sensitization against allergens in general $[8,9]$. Additionally, this organic dust is composed of feed particles, dander and gases [7].

Besides composition size and density of particle matter existent in poultry dust can influence health of workers exposed. Additionally, since particle size is an important factor for aerosolization research into bioaerosol contamination at different particle size fractions is important [10].

The size of airborne particles is normally described in terms of aerodynamic diameter which is equivalent to that of sphere of unit density that has the same terminal settling velocity. This ranges in size from the smallest particles that penetrate to the lung alveoli, the gas exchange region of the lungs, to particles of $100 \mu \mathrm{m}$ aerodynamic diameter. Above this size gravitational effects are considered to become significant compared with inertial effects for airborne particles [11]. Respirable dust is the fraction of airborne dust that reaches the gas exchange regions of the lung and is less than $7 \mu \mathrm{m}$ aerodynamic diameter in size $[11,12]$.

Epidemiological studies showed increased prevalence of respiratory symptoms and adverse changes in pulmonary function parameters in poultry workers $[4,5,8]$.

Also, especially when combined with ammonia, will act as a respiratory insult and can cause acute or chronic respiratory disease. In this case, respiratory impairment includes chronic bronchitis, hypersensitivity pneumonitis (allergic alveolitis), occupational asthma and toxin fever [7, 8].

Considering occupational exposure assessment is important to consider that data obtained must give accurate information to perform risk assessment and to permit define priorities concerning to appliance of preventive and protective 
measures. This is easier to accomplish if exposure assessment is done by activity allowing delineation of activity that involves higher exposure $[13,14]$.

In the case of poultry work tasks that give rise to the dust include: laying down of litter; populating poultry houses; handling and inspection of birds; vaccinating of birds; the routine upkeep and cleaning of houses during the growing or production period; catching or depleting of birds; removing litter and/or manure; and cleaning houses at the end of the production period, and other related or similar activities. However, there are some tasks that normally involve higher exposure to dust, namely brushing down surfaces and sweeping, and spreading litter [7]. The material used for poultry litter (wood shavings) is varied but normally can be constitute by pine shavings or sawdust or eucalyptus, and other various types of wood. In some regions are also used rice hulls, peanut, coffee, sugar cane, straw, hay, grass and paper processed [15].

A study was developed in a poultry unit aiming to know the task that represents higher exposure to dust. Also was identified the adequate preventive measure to apply in this case.

\section{Materials and methods}

A descriptive study was developed in order to assess exposure to particles in a poultry unit during different tasks, namely routine examination of the facility and floor turn over. The first task is done frequently and implies sometimes doing many things at the same time (removal of unhealthy birds, routine cleaning of pavilions during the growing or production period, feeding the animals) and the floor turnover is performed every week. In this last case mixed organic material (partially composted) held within the matrix of the bedding, in this case straw, accumulated over the rearing period may be released as airborne dust during this process.

\subsection{Particles measurement}

Environment evaluations were undertaken with portable direct-reading equipment (Lighthouse, model 3016 IAQ). Particles concentration measurement was performed in 5 different sizes (PM0.5; PM1.0; PM2.5; PM5.0; PM10). This option was considered because differentiation between particle size fractions is important in order to quantify penetration of dust within the respiratory system.

The measurements were taken near the workers' nose and during the mentioned tasks. All measurements were done continuously with a duration of 5 minutes.

\subsection{Preparation of poultry litter}

Poultry litter was sampled and prior to elemental analysis was lyophilized in an Edwards Modulyos freeze dryer (plate at $-40^{\circ} \mathrm{C}$; vacuum of $0.4 \mathrm{~atm}$ ). The poultry litter sample was milled using a Waring Blender HGB50E2, and then put into ultrapure polyethylene capsules of about 150-250 mg (three replicates; 150$200 \mathrm{mg}$ each). 


\subsection{Irradiation of poultry litter}

All samples were irradiated at the Portuguese Research Reactor (RPI-ITN; Sacavém) for $5 \mathrm{~h}$ (samples), at a thermal neutron flux density of $2.25 \mathrm{x}$ $1012 \mathrm{n} \mathrm{cm}^{2} \mathrm{~s}^{-1}$, together with one disk (thickness: $125 \mathrm{~mm}$; diameter: $5 \mathrm{~mm}$ ) of an $\mathrm{Al} 0.1 \% \mathrm{Au}$ alloy as comparator. Gamma spectra were acquired with a liquid N2-cooled, high-purity Ge detector. Samples were measured after 2-3 days and 3-4 weeks.

Disks of the alloy $\mathrm{Al}-0.1 \% \mathrm{Au}$ were irradiated together in order to apply the INAA k0-standardized (software version 3.21) methodology [16], and were measured for 5-10 min 1 week after the irradiation.

\section{Results}

In all the tasks considered PM5.0 (particles of dimension $5.0 \mu \mathrm{m}$ or less) and PM10.0 (particles of dimension $10 \mu \mathrm{m}$ or less) were the sizes with higher concentrations values (Figure 1).

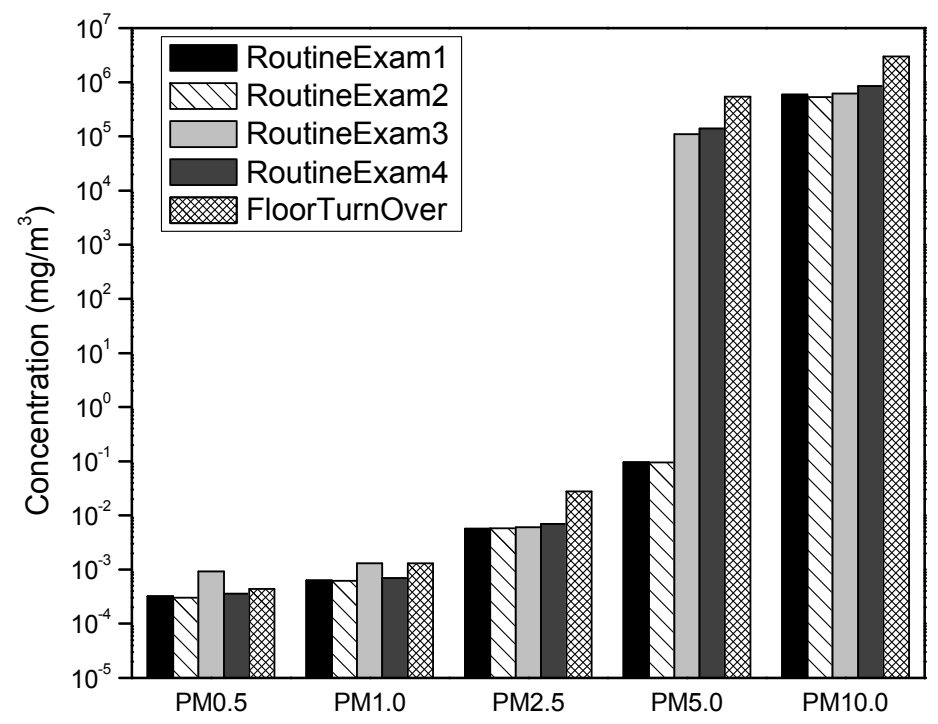

Figure 1: Results of particle concentrations by particle size on different tasks $\left(\mathrm{mg} / \mathrm{m}^{3}\right)$.

Floor turned over was the task that represents higher exposure in almost all particles sizes, with exception to PM0.5. Considering the distribution in particle size for this particular task, the highest concentration was obtained in PM10 (3.0E6 mg. $\mathrm{m}^{-3}$, five times higher than PM5.0).

Considering the results of particles per size it is possible to affirm that all tasks have similar concentrations. The exceptions go to PM5.0 with significant 
differences between Routine Examination 1 and 2 with Routine Examination 3, 4 and Floor Turn Over.

To compare data obtained in the different particles sizes (PM0.5, PM1.0, PM2.5, PM5.0 and PM10), we used the Friedman Test and correspondent pairwise comparisons. The results show statistically significant differences between different sizes $\left(\chi_{4}^{2}=20,00 ; \mathrm{p}=0.000\right)$ and through pairwise comparisons, we conclude that PM0.5 differs significantly from PM5.0 $(\mathrm{p}=0.027)$ and PM10 $(\mathrm{p}=0.001) ;$ PM1.0 differs significantly from PM10 $(\mathrm{p}=0.027)$. PM10 is what turns out to have higher values and PM0.5 the lowest values.

Considering results obtained from irradiation of poultry litter sample, concentrations of $\mathrm{As}, \mathrm{Ba}, \mathrm{Br}, \mathrm{Ca}, \mathrm{Co}, \mathrm{Cr}, \mathrm{Cs}, \mathrm{Fe}, \mathrm{K}, \mathrm{La}, \mathrm{Mg}, \mathrm{Na}, \mathrm{Sb}, \mathrm{Sc}$, Se and $\mathrm{Zn}$ are shown in Figure 2.

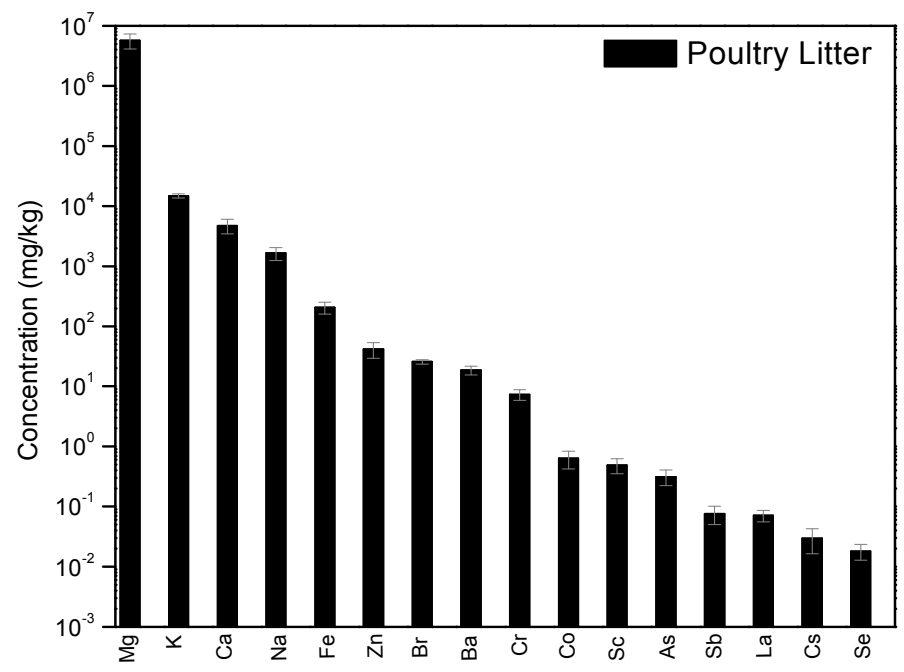

Figure 2: Chemical elements concentration on poultry litter.

According to Combs and his co-workers $\mathrm{Ca}, \mathrm{Na}, \mathrm{K}$ and $\mathrm{Mg}$ are considering macronutrients. Iron, Arsenic, Cobalt and Zinc are considering trace minerals [17].

The chemical element with the highest concentration was $\mathrm{Mg}\left(5.7 \mathrm{E} 10^{6}\right.$ $\mathrm{mg} / \mathrm{kg})$, followed by $\mathrm{K}(1.5 \mathrm{E} 4 \mathrm{mg} / \mathrm{kg}), \mathrm{Ca}(4.8 \mathrm{E} 4 \mathrm{mg} / \mathrm{kg}), \mathrm{Na}(1.7 \mathrm{E} 3 \mathrm{mg} / \mathrm{kg}), \mathrm{Fe}$ $(2.1 \mathrm{E} 2 \mathrm{mg} / \mathrm{kg})$ and $\mathrm{Zn}(4.2 \mathrm{E} 1 \mathrm{mg} / \mathrm{kg})$.

\section{Discussion}

The sources of dust from a poultry facility include dried fecal matter and urine, skin flakes, ammonia, carbon dioxide, pollens, feed and litter particles, feathers (which produce allergen dandruff), grain mites, fungi, spores, bacteria, viruses 
and their constituents, peptidoglycan, $\beta$-glucan, mycotoxin and endotoxin [10]. As mentioned recently in the study developed by the Health and Safety Executive of United Kingdom [18] particular attention should be given to identifying and assessing the controls for any short-term exposures to poultry dust which involve markedly higher concentrations than the long-term average. In addition, it is important to consider that intense exposures of short duration are a special concern because the high concentration produces a high dose rate into the body and target tissue. As a result, these kinds of exposures can produce more and different effects than the same administered dose given with less intensity over a longer time period $[19,20]$.

In the case of floor turn over, only being performed once a week, we have to consider that concentration results are particularly high compared with the other tasks. Moreover, this task was performed without any respiratory protection device and this is the usual way that poultry workers perform this task.

For instance, a study developed by Louhelainen and colleagues during animal feeding presented results of total particulate matter that ranged from 5.7 to 37.6 mg. $\mathrm{m}^{-3}$ with a mean of $13 \mathrm{mg} \cdot \mathrm{m}^{-3}[7,21]$. In this study, this specific task (animal feeding) obtained lower values when comparing with our results.

Ellen et al. [22] have verified that dust concentrations in poultry facilities can range from 0.02 to $81.33 \mathrm{mg} \cdot \mathrm{m}^{-3}$ for inhalable dust and 0.01 to $6.5 \mathrm{mg} \cdot \mathrm{m}^{-3}$ for respirable dust. Our results showed the same tendency: higher density in size PM5.0 and, principally, in size PM10. Data of our study showed concentrations of respirable dust ranged between 3.0E-4 and 5.4E5 mg. ${ }^{-3}$. These high presence of particles in the respirable range $(<5-7 \mu \mathrm{m})$ means that poultry dust particles can penetrate into the gas exchange region of the lung. Larger particles (PM10) present a range concentration's from 5.3E5 and 3.0E6 mg.m ${ }^{-3}$. Exposure to this last case of particles can also cause disease by impacting in the upper and larger airways below the vocal cords.

Another issue which is important to take into account is the poultry litter. Litter is a source of dust production and is used in floor-housed operations but not in cage-housed facilities. These differences coincide with observations of greater dust concentrations in floor-housed poultry facilities, the case of all the poultry units consider by this study [10]. The importance of the poultry litter study comes from the fact that according to FAO (2009) one of the potential pollutants and issues related to poultry production is litter (bedding materials such as sawdust, wood, shavings, straw and peanut or rice hulls) [23].

By this reason and by the fact that several million tons of poultry litters are generated annually by poultry farms it is so important to study the poultry litter composition [24]. The way that the disposal of poultry litter is made could lead to a public health problem. The poultry litter could be used as fertilizer to the agriculture because this is full of nutrients and is beneficial to crop soil. The problem appears when the poultry litters are contaminated by chemical elements. These elements may accumulate in the soils or plants or may be leached into groundwater [25].

According to Toor et al. [27] an addition of some chemical elements providing from poultry litters to soils would be lower than the US EPA annual 
application limits of trace elements for biosolids [26]. However, repeating this procedure could load the soils with trace elements above environmental thresholds.

A study developed by Combs and his co-workers shows different concentrations of trace elements when compared with this study. The concentrations of $\mathrm{Ca}, \mathrm{Na}, \mathrm{Mg}, \mathrm{Fe}$ and $\mathrm{Zn}$ were the highest values determined with $64.8,7.8,7.6,3$ and $0.48 \mathrm{mg} / \mathrm{kg}$, respectively [17]. The same elements were found in this study in high concentrations, but with orders of magnitude much higher when compared with the Combs study.

Beyond the serious problems associated with the use of poultry litter contaminated as fertilizer in agriculture soils is important to understand that poultry workers may be exposed to the same contaminants. The neutron activation analysis made in poultry sample showed that it was contaminated with toxic elements. So, whether poultry litter was contaminated with chemical elements is possible that poultry workers were also expose with the same elements by inhalation. This happens due the fact that developed tasks by workers promote the re-suspension of particles and as previously referred both inhaled and respirable particles were presented in high concentrations.

Many studies have already showed that poultry workers may develop health problems providing by air contaminants present in the workplace. Radon et al. [4] showed that poultry workers are exposed to high concentrations of environmental factors, such as dust, and have lower mean lung function. Another study compared the poultry workers with a control group and revealed a significantly higher prevalence of chronic cough, chronic phlegm, chronic bronchitis, and chest tightness in the first group than second group [28].

All this evidence shows the importance of studying this setting, and also strengthening the need to implement mitigation measures to avoid exposure.

Study developed pretend to reveal the tasks with higher exposure to poultry dust and those diverse tasks represent different risks and this implicate appliance of protective measures with a different priority. Using a respiratory protection device all day could be considered a challenge to poultry workers. However, with this kind of information, obtained by exposure assessment performed by task, it is possible to inform the workers what are the tasks that involve a higher risk and, additionally, where investment in collective protective measures can have higher impact in preventing respiratory diseases. The results show that floor turn over represents high exposure to dust and this information justifies the investment for instance in a vehicle fitted with a fully enclosed, ventilated cab and filtered air intake.

It is important also to consider that some preventive measures may decrease the exposure of the workers to poultry dust but could increase exposure to other contaminants. For example, the application of water mists can reduce particle suspension or re-suspension during operations but can increase relative humidity, which facilitates ammonia production and microbial growth. Therefore, occupational health interventions can be complex and must consider all risk factors present in this occupational setting. 


\section{Conclusions}

Poultry dust is a complex mixture of organic and inorganic materials as well as microbiological and invertebrate contaminants. There is evidence in other studies that inhalation exposure to these materials at the levels likely to be encountered in commercial poultry production could trigger allergic respiratory disease and exacerbate existing respiratory allergy.

The evidence of possible negative health effects suggests a need of remediation.

Each employee should be given information about the health risks associated with exposure to poultry dust and subsequently promote the use of respiratory protection devices when other protection resources are not available.

\section{References}

[1] Kogevinas M, Anto J, Sunyer J, Tobias A, Kromhout H \& Burney P: Occupational asthma in Europe and other industrialized areas: a population based study. Lancet, 353: pp. 1750-1754, 1999.

[2] Senthilselvan A, Dosman J, Kirychuk S, Barber E, Rhodes C, Zhang Y et al: Accelerated lung function decline in swine confinement workers. Chest, 111: pp. 1733-1741, 1997.

[3] Novak D: Prevalence and risk factors for airway diseases in farmers: a new EC multicentre project. Ann Agric Environ Med, 1: pp. 81-82, 1994.

[4] Radon K, Weber C, Iversen M, Danuser B, Pedersen S \& Nowak D: Exposure assessment and lung function in pig and poultry farmers. Occup Environ Med, 58: pp. 405-410 (2001).

[5] Rimac D, Macan J, Varnai V, Vučemilo M, Matković K, Prester L, Orct T, Trošić I \& Pavičic I: Exposure to poultry dust and health effects in poultry workers: impact of mould and mite allergens. Int Arch Occup Environ Health, 83: pp. 9-19, 2010.

[6] Alencar M, Nääs I \& Gontijo: Respiratory Risks in Broiler Production Workers. Brazilian Journal of Poultry Science, 6, 1: pp. 23-29, 2004.

[7] Whyte, R. T. Occupational exposure of poultry stockmen in current barn systems for egg production in the United Kingdom. British Poultry Science, 43: 3, 364-373, 2002.

[8] Rylander R: Lung diseases caused by organic dusts in the farm environment. American Journal of Industrial Medicine, 10: 221-227, 1986.

[9] Rylander R \& Carvalheiro M: Airways inflammation among workers in poultry houses. Int Arch Occup Environ Health, 79: pp. 487-490, 2006.

[10] Just N, Duchaine C \& Singh B: An aerobiological perspective of dust in cage-housed and floor-housed poultry operations. Journal of Occupational Medicine and Toxicology, 4:13, 2009.

[11] Vincent J: Aerosol Sampling. Science and Practice. Chichester, John Wiley, 1989.

[12] Vincent J \& Mark D: The basis of dust sampling in occupational hygiene: a critical review. Annals of Occupational Hygiene, 24: pp. 375-390, 1981. 
[13] Susi P \& Schneider S: Database needs for a task-based exposure assessment model for construction. Applied Occupational and Environmental Hygiene, 10; 4: pp. 394-399, 1995.

[14] Viegas S, Prista J \& Gomes M: Exposure assessment : the influence of environmental monitoring methodology. In Brebbia $\mathrm{C}$, ed. lit. Environmental health risk. Transactions of the Wessex Institute Press, 2009.

[15] Fernandes F: Poeiras em Aviários. Rev. Bras. Med. Trab., Belo Horizonte 2,4 pp. 253-262, 2004.

[16] De Corte F: The k0-standardization method - a move to the optimization of neutron activation analysis. Aggregé Thesis, Gent University, Belgium, 1987.

[17] Combs S, Peters J \& Zhang B: Micronutrient Status of Manure. University of Wisconsin-Extension, 2001.

[18] HSE. Statement of evidence: Respiratory hazards of poultry dust Health and Safety Executive 03/09 14 of 14 pages.

[19] Smith T: Studying peak exposure: toxicology and exposure statistics. In: Marklund S, ed. lit. - Exposure assessment in epidemiology and practice. Stockholm : National Institute for Working Life, pp. 207-209, 2001.

[20] Preller L, Burstyn L \& De Pater N: Characteristics of peaks of inhalation exposure to organic solvents. The Annals of Occupational Hygiene. 48: 7 pp. 643-652, 2004.

[21] Louhelainen K, Kangas J, Husman K \& Terho E: Total concentrations of dust in the air during farm work. European Journal of Respiratory Diseases, 71 152: pp. 73-79, 1987.

[22] Ellen, HH; Bottcher, RW, von Wachenfelt, E, Takay, H. Dust levels and control methods in poultry houses. J Agric Saf Health, 6: 275-282, 2000.

[23] Williams C: Poultry waste management in developing countries. Food and Agriculture Organization of the United Nations, Poultry Development Review, 2009.

[24] Ekperigin H: Use of poultry litter or manure as a fertilizer for croplands: impact on animal and public health. FDA Veterinarian Newsletter. 71(3), 2000.

[25] Gupta G \& Charles S: Trace elements in soils fertilized with poultry litter. Poult. Sci, 78 (12): pp. 1695-1698, 1999.

[26] US EPA, Background report on fertilizer use, contaminants and regulations. EPA 747-R-98-003, 1999.

[27] Toor G, Haggard E, Donoghue A: Water extractable trace elements in poultry litters and granulated products. Poultry Science Association, 16(3): pp. 351-360, 2007.

[28] Zuskin E, Mustajbegovic J, Schachter E, Ker J \& Rienzi N, Goswami S, Marom Z \& Maayani S: Respiratory function in poultry workers and pharmacologic characterization of poultry dust extract. Environmental Research, 70: pp. 11-19, 1995. 